Journal of Telenursing (JOTING)

Volume 1, Nomor 2, Desember 2019

e-ISSN: 2684-8988

p-ISSN: 2684-8996

DOI: https://doi.org/10.31539/joting.v1i2.982

\title{
FAKTOR YANG BERHUBUNGAN DENGAN KEJADIAN ANEMIA PADA IBU HAMIL TRIMESTER III
}

\author{
Anjelina Puspita Sari ${ }^{1}$, Romlah $^{2}$ \\ Universitas Katolik Musi Charitas ${ }^{1,2}$ \\ angelinaps88@gmail.com ${ }^{1}$
}

\begin{abstract}
ABSTRAK
Tujuan penelitian ini adalah untuk mengetahui faktor yang berhubungan dengan kejadian anemia pada ibu hamil trimester III. Desain penelitian Penelitian ini merupakan studi cross sectional. Hasil penelitian ini menunjukkan tidak terdapat hubungan yang signifikan antara umur dengan anemia pada ibu hamil trimester III $(\mathrm{p}=0,23)$. Hasil penelitian ini menunjukkan terdapat hubungan yang signifikan antara gravida dengan kejadian anemia pada ibu hamil trimester III ( $\mathrm{p}=0,041)$. Hasil penelitian ini juga menunjukkan hubungan yang signifikan antara jarak kehamilan dengan kejadian anemia pada ibu hamil trimester III $(\mathrm{p}=0,04)$. Hasil penelitian ini menunjukkan tidak terdapat hubungan yang signifikan antara frekuensi ANC dengan kejadian anemia pada ibu hamil trimester III $(p=0,30)$. Simpulan, ini adalah terdapat hubungan yang signifikan antara jumlah kehamilan dan jarak kehamilan dengan kejadian anemia pada ibu hamil trimester III. Tidak terdapat hubungan yang signifikan antara umur dan frekuensi ANC dengan kejadian anemia pada ibu hamil trimester III.
\end{abstract}

Kata Kunci: Faktor Anemia, Ibu Hamil Trimester Tiga

\section{ABSTRACT}

The purpose of this study was to determine the factors associated with the incidence of anemia in third trimester pregnant women. The research design of this research is a cross sectional study. The results of this study showed that there was no significant relationship between age and anemia in third trimester pregnant women $(p=0.23)$. The results of this study indicated that there was a significant relationship between gravida and the incidence of anemia in third trimester pregnant women $(p=0.041)$. The results of this study also showed a significant relationship between pregnancy and the incidence of anemia in third trimester pregnant women $(p=0.04)$. The results of this study showed that there was no significant relationship between the frequency of ANC and the incidence of anemia in third trimester pregnant women $(p=0.30)$. In conclusion, this is a significant relationship between pregnancy and pregnancy interval with the incidence of anemia in third trimester pregnant women. There is no significant relationship between age and frequency of ANC with the incidence of anemia in third trimester pregnant women.

Keywords: Anemia Factors, Three Trimester Pregnant Women 


\section{PENDAHULUAN}

Anemia adalah suatu kondisi dimana jumlah dan ukuran sel darah merah atau konsentrasi hemoglobin dibawah nilai batas normal (11 gr/dL), akibatnya dapat mengganggu kapasitas darah untuk mengangkut oksigen kesekitar tubuh. Anemia merupakan indikator gizi buruk dan kesehatan yang buruk. Anemia pada Ibu hamil sangat terkait dengan mortalitas dan morbiditas pada ibu dan bayi, termasuk resiko keguguran, lahir mati, prematuritas, dan berat bayi lahir rendah (WHO, 2014).

Anemia dalam kehamilan adalah kadar Hemoglobin $(\mathrm{Hb})$ dibawah $11 \mathrm{~g} / \mathrm{dL}$ disertai turunnya heamtokrit dan jumlah sel darah merah dibawah nilai normal (WHO, 2011; Rukiyah, 2010). Hemoglobin adalah protein yang ada di dalam sel darah merah, protein inilah yang memberikan warna merah pada darah. Hemoglobin berbentuk bulat yang terdiri dari 4 subunit polipeptida, setiap unit mengandung satu bagian heme yang berkonjugasi dengan suatu polipeptida (Sherwood, 2011). Hemoglobin memiliki fungsi bergabung dengan oksigen dalam paru dan kemudian melepaskan oksigen ini di dalam kapiler jaringan. Hemoglobin juga membantu mengangkut karbon dioksida dari sel jaringan kembali ke paru (Guyton \& Hall, 2011).

Program Pemerintah mewajibkan standar pelayanan asuhan antenatal salah satunya dengan pemberian 90 tablet zat besi selama kehamilan (Kemenkes RI, 2017). Manfaat zat besi untuk tubuh, di antaranya membantu menjaga tubuh agar tidak mengalami anemia. Ibu hamil yang kekurangan cadangan zat besi dapat menyebabkan anemia defisiensi zat besi (Sudargo et al., 2018).

Kebutuhan zat besi akan meningkat dari hanya $0,8 \mathrm{mg}$ per hari selama trimester pertama, menjadi 6-7 mg dan volume darah akan meningkat sampai 35\% memasuki trimester dua dan ketiga, ini ekuivalen dengan 450mg zat besi untuk memproduksi sel-sel darah merah. Sel darah merah harus mengangkut oksigen lebih banyak untuk janin. Sedangkan saat melahirkan perlu tambahan besi 300 - 350 mg akibat kehilangan darah (Cunningham et al., 2014).

Anemia menyebabkan peningkatan resiko komplikasi pada saat kehamilan, persalinan, dan nifas. Anemia besi mengakibatkan terjadinya abortus, persalinan prematur, perkembangan janin terhambat, resiko infeksi, hiperemesis gravidarum, perdarahan antepartum, ketuban pecah dini, meningkatnya insiden preeklamsi dan sepsis serta peningkatan curah jantung dan peningkatan beban kerja pemompaan jantung (Guyton \& Hall, 2011).

Kejadian anemia ibu hamil di dunia memiliki angka prevalensi yang cukup tinggi. Terbukti dari sejumlah penelitian yang dilakukan dibeberapa negara. Salah satunya di Brazil menunjukan prevalensi anemia 50\%. Di Amerika masih ditemukan anemia sebesar 24,1\%, Eropa 25,1 \%, Pasifik Barat 30,7\%, Timur mediterania 44,2 \%, Asia Tenggara 48,2\%, dan Afrika 57,1\%. Dua wilayah sub Sahara Afrika dan Asia selatan merupakan 88\% kematian Ibu diseluruh dunia. Sahara Arika menderita rasio kematian ibu tertinggi 546 kematian ibu per 100.000 kelahiran hidup atau 201.000 kematian ibu setahun. Ini adalah dua pertiga ( 66\%) dari semua kematian ibu pertahun di seluruh dunia. Asia selatan mengikuti dengan rasio kematian ibu 182 atau 66.000 kematian ibu setahun (WHO, 2015).

Indonesia angka anemia pada ibu hamil masih cukup tinggi. Angka anemia pada ibu hamil di perkotaan 36,4 \% dan di pedesaan 37,8 \%. Menurut data riskesdas kelompok ibu hamil merupakan salah satu kelompok yang berisiko tinggi mengalami anemia, meskipun 
anemia yang dialami umumnya merupakan anemia relatif akibat perubahan fisiologis tubuh selama kehamilan. Anemia pada populasi ibu hamil menurut kriteria yang ditentukan WHO dan pedoman Kemenkes 1999, yakni sebesar 37,1\% Hal ini menunjukkan angka anemia di Indonesia mendekati masalah kesehatan masyarakat berat (severe public health problem) (Kementrian Kesehatan RI, 2013).

Data hasil Riset Kesehatan Dasar (Riskesdas) menunjukkan prevalensi anemia pada ibu hamil di Indonesia sebesar 37,1\%, data ini menunjukkan bahwa anemia gizi besi masih menjadi masalah kesehatan masyarakat Indonesia (Kemenkes RI, 2013). Data dinas kesehatan kota Palembang pada tahun 2013 sebanyak 1.001 (3,0\%) ibu hamil dengan anemia dari 32.302 ibu hamil, tahun 2014 jumlah ibu hamil dengan anemia sebanyak 1.028 (3,0\%) dari 33.309 ibu hamil (Dinas Kesehatan Kota Palembang, 2014).

Menurut departemen gizi dan kesehatan masyarakat tahun 2012 presentase anemia pada wanita hamil seiring bertambahnya usia kehamilan terus meningkat yaitu trimester I sebanyak 8\%, trimester II sebanyak 12\%, dan trimester III sebanyak 29\%. Di Indonesia penyebab utama kematian Ibu sama juga dengan dunia internasional yaitu akibat perdarahan dimana anemia pada ibu hamil menjadi penyebab utama terjadinya perdarahan dan menjadi faktor utama penyebab kematian (Kementerian Kesehatan RI, 2014).

Faktor yang mempengaruhi kondisi anemia adalah jumlah kehamilan dan jarak kelahiran. Paritas lebih dari 3 mempunyai angka kematian maternal lebih tinggi. Paritas yang tinggi dan jarak kelahiran $<2$ tahun merupakan faktor resiko terjadinya anemia (Apriyanti, 2015 \& Padila, 2015). Faktor tidak lansung yang mempengaruhi kadar $\mathrm{Hb}$ ibu hamil yaitu frekuensi ANC, paritas, umur ibu hamil dan jarak kehamilan (Sumiyarsi et al., 2018). Menurut Krisnawati et al., (2015) beberapa faktor yang dapat menyebabkan terjadinya anemia dalam kehamilan diantaranya adalah gravida, umur, paritas, tingkat pendidikan, status ekonomi dan kepatuhan konsumsi tablet Fe.

Banyak faktor yang mempengaruhi kejadian anemia karena itu dibutuhkan skrining untuk mencari faktor yang berhubungan dengan kejadian anemia pada Ibu Hamil. Berdasarkan data penigkatan kejadian anemia serta beberapa faktor yang berhubungan dengan kejadian anemia, maka penulis tertarik melakukan penelitian mengenai faktor yang berhubungan dengan kejadian anemia pada Ibu hamil trimester III.

Hasil penelitian yang dilakukan oleh Sulistiyanti (2015) yang menunjukan bahwa adanya hubungan antara pengetahuan, umur, tingkat kepatuhan dalam mengkonsumsi tablet Fe, status ekonomi dengan kejadian anemia pada ibu hamil. Disamping Itu hasil penelitian yang dilakukan oleh Asyirah (2012) menunjukan bahwa adanya hubungan antara pengetahuan, frekuensi antenatal care, dan kepatuhan ibu hamil dalam mengkonsumsi tablet Fe dengan kejadian anemia pada ibu hamil. Penelitian yang dilakukan oleh Abidah (2013) menunjukan hasil bahwa adanya hubungan antara pengetahuan, frekuensi antenatal, status ekonomi, status gizi dengan kejadian anemia pada ibu hamil.

\section{METODE PENELITIAN}

Jenis penelitian ini merupakan jenis penelitian analitik kuantitatif dengan menggunakan desain cross sectional. Penelitian ini bertempat di Kecamatan 11 Ilir Kota Palembang, dilaksanakan Bulan Juni- Agustus 2018. Populasi target dalam penelitian ini adalah semua Ibu Hamil Trimester III di Kecamatan 11 Ilir Kota Palembang. Sampel pada penelitian ini adalah bagian dari populasi yang dipilih secara purposive sampling berjumlah 
50 Ibu hamil trimester III yang memenuhi kriteria inklusi. Teknik analisa data menggunakan analisis chi-square. Pengambilan sampel dilakukan setelah calon responden diberikan penjelasan tentang latar belakang, tujuan dan manfaat penelitian serta mendapatkan persetujuan tertulis dari subjek penelitian, selanjutnya dibagikan kuesioner penelitian dan dilakukan pemeriksaan Hb dengan Metode Sianemethemoglobin. Responden dikelompokan menjadi dua yaitu tidak anemia dengan kadar $\mathrm{Hb} \geq 11 \mathrm{~g} / \mathrm{dL}$ dan anemia dengan kadar $\mathrm{Hb}<11 \mathrm{~g} / \mathrm{dL}$.

\section{HASIL PENELITIAN}

Tabel. 1

Hasil Analisa Univariat

\begin{tabular}{|c|c|c|c|}
\hline No & Karakteristik & Frekuensi (f) & Presentase (\%) \\
\hline \multirow{3}{*}{1.} & Umur & & \\
\hline & 20-35 tahun & 45 & 90 \\
\hline & $>35$ & 5 & 10 \\
\hline \multirow{5}{*}{2.} & Pendidikan & & \\
\hline & SD & 5 & 10 \\
\hline & SLTP & 11 & 22 \\
\hline & SMA & 32 & 64 \\
\hline & PT & 2 & 4 \\
\hline \multirow{3}{*}{3.} & Pekerjaan & & \\
\hline & Tidak Bekerja & 46 & 92 \\
\hline & Bekerja & 4 & 8 \\
\hline \multirow{3}{*}{4.} & Hemoglobin & & \\
\hline & Tidak Anemia & 40 & 80 \\
\hline & Anemia & 10 & 20 \\
\hline
\end{tabular}

Berdasarkan tabel 1 usia responden diketahui mayoritas responden berumur 30-35 tahun berjumlah 45 orang $(90 \%)$ sedangkan yang berumur $>35$ tahun berjumlah 5 orang (10\%). Responden berdasarkan tingkat pendidikan, diketahui mayoritas responden berpendidikan SMA berjumlah 32 orang (64\%), sedangkan yang paling sedikit adalah reponden yang tamat perguruan tinggi berjumlah 2 orang (4\%). Responden berdasarkan pekerjaan diketahui mayoritas responden adalah Ibu Rumah Tangga atau tidak bekerja berjumlah 46 orang (92\%), sedangkan responden yang bekerja berjumlah 4 orang (8\%). Hasil analisa univariat dari 50 responden yang tidak mengalami anemia sebanyak 40 orang (80\%) sedangkan yang mengalami anemia sebanyak 10 orang $(20 \%)$.

Tabel. 2

Hubungan Umur dengan Kejadian Anemia

\begin{tabular}{cccccccccc}
\hline \multirow{2}{*}{ Umur } & \multicolumn{4}{c}{ Hemoglobin } & \multicolumn{2}{c}{ Jumlah } & & OR \\
\cline { 2 - 7 } & $\begin{array}{c}\text { Tidak Anemia } \\
(\mathrm{n}=40)\end{array}$ & $\%$ & $\begin{array}{c}\text { Anemia } \\
(\mathrm{n}=10)\end{array}$ & $\%$ & $\mathrm{n}$ & $\%$ & $P$ & $(\mathrm{CI} 95 \%)$ \\
\hline $30-35$ & 37 & 82,2 & 8 & 17,8 & 45 & 100 & & 0,324 \\
$>35$ & 3 & 60 & 2 & 40 & 5 & 100 & 0, & $0,04-2,26)$ \\
\hline Jumlah & 40 & 80 & 10 & 20 & 50 & 100 & \\
\hline
\end{tabular}


Berdasarkan tabel 2 dari 50 responden yang berumur 20-35 tahun yang memiliki kadar hemoglobin normal atau tidak anemia sebanyak 37 responden dan yang mengalami anemia sebanyak 8 responden. Responden yang berumur $>35$ tahun yang tidak anemia sebanyak 3 orang dan yang mengalami anemia sebanyak 2 orang.

Berdasarkan uji Chi-Square didapatkan $P$ value 0,23 lebih besar dari 0,05, maka tidak ada hubungan signifikan antara umur dengan kejadian anemia pada ibu hamil terimester III.

Tabel. 3

Hubungan Gravida dengan Kejadian Anemia

\begin{tabular}{|c|c|c|c|c|c|c|c|c|}
\hline \multirow[b]{2}{*}{ Gravida } & \multicolumn{4}{|c|}{ Hemoglobin } & \multicolumn{2}{|c|}{ Jumlah } & \multirow[b]{2}{*}{$P$} & \multirow[b]{2}{*}{$\begin{array}{c}\text { OR } \\
\text { (CI 95\%) }\end{array}$} \\
\hline & $\begin{array}{c}\text { Tidak } \\
\text { Anemia } \\
(\mathrm{n}=40)\end{array}$ & $\%$ & $\begin{array}{c}\text { Anemia } \\
(n=15)\end{array}$ & $\%$ & $\mathrm{n}$ & $\%$ & & \\
\hline Primigravida & 18 & 94,7 & 1 & 5,3 & 19 & 100 & \multirow{3}{*}{0,041} & \multirow{3}{*}{$\begin{array}{l}0,136 \\
(0,16- \\
1,175)\end{array}$} \\
\hline Multi & 22 & 71,0 & 9 & 29,0 & 31 & 100 & & \\
\hline Jumlah & 40 & 80,0 & 10 & 20,0 & 50 & 100 & & \\
\hline
\end{tabular}

Berdasarkan tabel 3 dari 50 responden primigravida yang tidak mengalami anemia sebanyak 18 responden dan yang mengalami anemia sebanyak 1 responden. Responden multigravida yang tidak mengalami anemia sebanyak 22 responden dan yang mengalami anemia sebanyak 9 responden.

Berdasarkan uji chi-square didapatkan $p$ value 0,041 lebih kecil dari 0,05, maka ada hubungan signifikan antara gravida dengan kejadian anemia pada ibu hamil trimester III. Dari analisis keeratan hubungannya menunjukkan nilai Odd Ratio (OR) 0,136 yang berarti bahwa responden dengan jumlah kehamilan multi 0,136 kali memiliki resiko mengalami anemia dibandingkan dengan responden primigravida.

Tabel. 4

Hubungan Jarak Kehamilan dengan Kejadian Anemia

\begin{tabular}{ccccccccc}
\hline \multirow{2}{\text{Jarak}}{$\begin{array}{c}\text { Kehamil } \\
\text { an }\end{array}$} & $\begin{array}{c}\text { Tidak } \\
\text { Anemia } \\
(\mathrm{n}=40)\end{array}$ & $\%$ & $\begin{array}{c}\text { Anemia } \\
(\mathrm{n}=15)\end{array}$ & $\%$ & $\mathrm{n}$ & $\%$ & $P$ & $\begin{array}{c}\text { OR } \\
(\mathrm{CI} 95 \%)\end{array}$ \\
\hline $\begin{array}{c}<2 \text { tahun } \\
\begin{array}{c}\geq 2 \\
\text { tahun }\end{array}\end{array}$ & 14 & 66,7 & 7 & 33,3 & 21 & 100 & & 4,33 \\
\cline { 1 - 5 } Jumlah & 46 & 89,7 & 3 & 10,3 & 29 & 100 & 0,04 & $\begin{array}{c}(0,96- \\
19,43)\end{array}$ \\
\hline
\end{tabular}

Berdasarkan tabel 4 dari 50 responden dengan jarak kehamilan $<2$ tahun yang tidak mengalami anemia sebanyak 14 responden dan yang mengalami anemia sebanyak 7 responden. Responden dengan jarak kehamilan $>2$ tahun yang tidak mengalami anemia sebanyak 26 responden dan yang mengalami anemia sebanyak 3 responden. 
Berdasarkan uji chi-square didapatkan $p$ value 0,045 lebih kecil dari 0,05, maka ada hubungan signifikan antara jarak kehamilan dengan kejadian anemia pada ibu hamil trimester III. Dari analisis keeratan hubungannya menunjukkan nilai Odd Ratio (OR) 4,33 yang berarti bahwa responden dengan jarak kehamilan $<2$ tahun 4,33 kali memiliki resiko mengalami anemia dibandingkan dengan responden dengan jarak kehamilan $>2$ tahun.

Tabel. 5

Hubungan Frekuensi ANC dengan

Kejadian Anemia

\begin{tabular}{|c|c|c|c|c|c|c|c|c|}
\hline \multirow[b]{2}{*}{$\begin{array}{l}\text { Frekuensi } \\
\text { ANC }\end{array}$} & \multicolumn{4}{|c|}{ Hemoglobin } & \multicolumn{2}{|c|}{ Jumlah } & \multirow[b]{2}{*}{$P$} & \multirow[b]{2}{*}{$\begin{array}{c}\text { OR } \\
(\mathrm{CI} \\
95 \%)\end{array}$} \\
\hline & $\begin{array}{c}\text { Tidak } \\
\text { Anemia } \\
(n=40)\end{array}$ & $\%$ & $\begin{array}{c}\text { Anemia } \\
(n=15)\end{array}$ & $\%$ & $\mathrm{n}$ & $\%$ & & \\
\hline$<4$ kali & 13 & 72,2 & 5 & 27,8 & 18 & 100 & \multirow{3}{*}{0,302} & \multirow{3}{*}{$\begin{array}{c}2,07 \\
(0,51- \\
8,46)\end{array}$} \\
\hline$\geq 4$ kali & 27 & 84,4 & 5 & 15,6 & 32 & 100 & & \\
\hline Jumlah & 40 & 80,0 & 10 & 20,0 & 50 & 100 & & \\
\hline
\end{tabular}

Berdasarkan tabel 5 dari 50 responden dengan frekuensi ANC $<4$ kali yang tidak mengalami anemia sebanyak 13 responden dan yang mengalami anemia sebanyak 5 responden. Responden dengan frekuensi ANC $\geq 4$ kali yang tidak mengalami anemia sebanyak 27 responden dan yang mengalami anemia sebanyak 5 responden.

Berdasarkan uji chi-square didapatkan $p$ value 0,302 lebih besar dari 0,05, maka tidak ada hubungan signifikan antara frekuensi ANC dengan kejadian anemia pada ibu hamil trimester III.

\section{PEMBAHASAN}

\section{Hubungan Umur dengan Kejadian Anemia}

Berdasarkan tabel 2 dari 50 responden yang berumur 20-35 tahun yang memiliki kadar hemoglobin normal atau tidak anemia sebanyak 37 responden dan yang mengalami anemia sebanyak 8 responden. Responden yang berumur $>35$ tahun yang tidak anemia sebanyak 3 orang dan yang mengalami anemia sebanyak 2 orang. Berdasarkan uji chisquare didapatkan $p$ value 0,23 lebih besar dari 0,05, maka tidak ada hubungan signifikan antara umur dengan kejadian anemia pada ibu hamil terimester III.

Penelitian ini bertolak belakang dengan penelitian Ningrum \& Syaifudin (2012) yang menyatakan bahwa ibu hamil dengan usia tidak aman $<20$ tahun dan $>35$ tahun sebanyak 26,1\% mengalami anemia dalam kehamilan, dan umur merupakan salah satu faktor terjadinya anemia pada ibu hamil. Umur $<20$ tahun dan $>35$ tahun merupakan umur yang resiko tinggi terhadap kehamilan dan persalinan. Peneltian ini juga bertolak belakang dengan penelitian Amini et al., (2018) yang menyatakan bahwa ada hubungan bermakna antara usia ibu dengan kejadian anemia. Penelitian Astriana (2017) menunjukan ada hubungan yang bermakna antara umur dengan kejadian anemia pada ibu hamil, menurutnya ibu hamil >35 tahun terkait dengan berbagai penyakit yang sering menimpa diusia ini. Penelitian Mariana et al., (2018) menunjukkan hasil dari 30 responden adalah hampir setengah dari responden $(26,7 \%)$ mengalami anemia pada rentang usia 25-34 tahun. 
Data ini menunjukan mayoritas ibu hamil berada pada usia reproduktif yaitu 20-35 tahun, walaupun ini merupakan usia aman untuk ibu hamil dan melahirkan tapi perlu juga diwaspadai kemungkinan terjadinya anemia, karena secara biologis mental sering terguncang pada periode ini yang berdampak pada pemunduran dan penurunan daya tahan tubuh sehingga bisa berdampak pada kesehatan tubuh seperti anemia.

\section{Hubungan Gravida dengan Kejadian Anemia}

Berdasarkan tabel 3 dari 50 responden primigravida yang tidak mengalami anemia sebanyak 18 responden dan yang mengalami anemia sebanyak 1 responden. Responden multigravida yang tidak mengalami anemia sebanyak 22 responden dan yang mengalami anemia sebanyak 9 responden. Berdasarkan uji chi-square didapatkan $P$ value 0,041 lebih kecil dari 0,05, maka ada hubungan signifikan antara gravida dengan kejadian anemia pada ibu hamil trimester III. Dari analisis keeratan hubungannya menunjukkan nilai Odd Ratio (OR) 0,136 yang berarti bahwa responden dengan jumlah kehamilan multi 0,136 kali memiliki resiko mengalami anemia dibandingkan dengan responden primigravida.

Penelitian ini sejalan dengan penelitian Oktaviani et al., (2016) yang menyatakan bahwa kadar $\mathrm{Hb}$ normal cenderung ditampilkan responden dengan paritas kurang dari 2, dimana pada responden dengan paritas multi lebih beresiko mengalami anemia. Qudsiah (2012) menyatakan semakin sering wanita melahirkan maka akan lebih besar resiko terjadi anemia. Penelitian Amirudin (2014) menunjukan bahwa paritas tinggi beresiko 1,454 kali terkena anemia dibandingkan dengan paritas rendah pada ibu hamil.

Kehamilan yang berulang menimbulkan kerusakan pada pembuluh darah dan dinding uterus dan mempengaruhi sirkulasi nutrisi ke janin. Jumlah persalinan juga berhubungan dengan anemia, jadi semakin sering Frekuensi kehamilan maka semakin sering resiko kehilangan darah dan zat besi yang berdampak pada penurunan Hb. Selain itu, Wanita primigravida pada penelitian ini sedikit yang mengalami anemia disebabkan perempuan yang hamil pertama kali cenderung memperhatikan kondisi bayinya yang sudah ditunggu kehadirannya sehingga ibu memperhatikan nutrisi yang Ia peroleh. Ibu Multigravida sering kali perhatiannya terbagi kepada anak yang lain, sehingga Ibu kadang kurang memperhatikan kondisi kehamilannya.

\section{Hubungan Jarak Kehamilan dengan Kejadian Anemia}

Berdasarkan tabel 4 dari 50 responden dengan jarak kehamilan $<2$ tahun yang tidak mengalami anemia sebanyak 14 responden dan yang mengalami anemia sebanyak 7 responden. Responden dengan jarak kehamilan $>2$ tahun yang tidak mengalami anemia sebanyak 26 responden dan yang mengalami anemia sebanyak 3 responden.

Berdasarkan uji chi-square didapatkan ada hubungan signifikan antara jarak kehamilan dengan kejadian anemia pada ibu hamil trimester III. Dari analisis keeratan hubungannya menunjukkan nilai Odd Ratio (OR) 4,33 yang berarti bahwa responden dengan jarak kehamilan $<2$ tahun 4,33 kali memiliki resiko mengalami anemia dibandingkan dengan responden dengan jarak kehamilan $>2$ tahun.

Jarak kehamilan yang baik minimal 2 tahun, jarak kehamilan yang kurang dari 2 tahun memungkinkan kondisi ibu belum pulih, sehingga zat besi yang ada dalam tubuhnya terbagi untuk pemulihan tubuhnya dan kebutuhan selama kehamilan berikutnya (Fatimah et 
al., 2011). Hasil penelitian ini sejalan dengan penelitian Yunita (2015) yang menyatakan bahwa ada hubungan antara jarak kehamilan dengan kejadian anemia.

Jarak kehamilan yang tidak terlalu dekat ( $>$ dari 2 tahun) dapat menciptakan suasana keluarga yang bahagia dan perhatian ibu beserta keluarga dapat terpusat pada kehamilan sehingga kondisi kehamilan dalam keadaan baik. Jarak kehamilan $>2$ tahun adalah jarak ideal kehamilan karena kondisi ibu sudah sepenuhnya siap untuk memulai kehamilan lagi, karena kalau jarak kehamilan yang terlalu dekat $(<2$ tahun) kondisi ibu belum sepenuhnya pulih sehingga saat terjadi kehamilan lagi kebutuhan zat besi terbagi untuk kebutuhan pemenuhan ibu dan kehamilannya, keadaan seperti ini yang menyebabkan ibu mengalami defiseinsi zat besi sehingga terjadi anemia defisiensi zat besi pada ibu hamil.

\section{Hubungan Frekuensi ANC dengan Kejadian Anemia}

Berdasarkan Tabel 5 dari 50 responden dengan frekuensi ANC $<4$ kali yang tidak mengalami anemia sebanyak 13 responden dan yang mengalami anemia sebanyak 5 responden. Responden dengan frekuensi ANC $\geq 4$ kali yang tidak mengalami anemia sebanyak 27 responden dan yang mengalami anemia sebanyak 5 responden. Berdasarkan uji chi-square didapatkan $P$ value 0,302 lebih besar dari 0,05, maka tidak ada hubungan signifikan antara frekuensi ANC dengan kejadian anemia pada ibu hamil trimester III.

Penelitian ini sejalan dengan penelitian Tanziha et al., (2016) yang menyatakan bahwa antenatal care tidak berhubungan dengan kejadian anemia, menurutnya antenatal care merupakan faktor protektif, sehingga masih perlu peningkatan kualitas pelayanan.

Penelitian ini bertentangan dengan penelitian Nanda \& Rodiani (2017) yang menyatakan bahwa keteraturan kunjungan antenatal yang baik dapat menurunkan angka kejadian anemia pada ibu hamil.

Pelayanan standar ANC paling sedikit 4 kali kunjungan diharapkan dengan kunjungan ini ibu dapat memperoleh penyuluhan terkait masalah kehamilannya seperti penyuluhan gizi dan konsumsi tablet tambah darah, antenatal care bersifat protektif sebelum terjadi masalah pada kesehatan ibu hamil sehingga diperlukan peningkatan kualitas pelayanan. Berdasarkan hasil penelitian ini walaupun responden telah melakukan kunjungan atenatal sesuai standar tidak serta merta diikuti kadar hemoglobin yang baik, tapi hal ini juga tergantung dari tingkat kepatuhan ibu dalam menjalankan nasihat atau anjuran yang diperoleh selama pemeriksaan kehamilan.

\section{SIMPULAN}

Terdapat hubungan yang signifikan antara jarak kehamilan dan jumlah kehamilan dengan kejadian anemia pada ibu hamil trimester tiga. Tidak terdapat hubungan yang signifikan antara umur dan frekuensi ANC dengan kejadian anemia pada ibu hamil trimester tiga.

\section{SARAN}

Diperlukan pemantauan pola makan ibu sehari-hari, diperlukan pemantauan kepatuhan ibu konsumsi tablet besi, diperlukan penelitian lebih lanjut mengenai faktor lain yang mempengaruhi anemia. 


\section{DAFTAR PUSTAKA}

Abidah, S., Dode, S., \& Ferial, E. W. (2013). Faktor-Faktor yang Mempengaruhi Terjadinya Anemia pada Ibu Hamil di Rumah Sakit Ibu dan Anak Siti Fatimah Makasar, 2(5)

Amini, A., Pamungkas, C. E., \& Harahap, A. P. (2018). Umur Ibu dan Paritas sebagai Faktor Resiko yang Mempengaruhi Kejadian Anemia pada Ibu Hamil di Wilayah Kerja Puskesmas Ampenan. Midwifery Journal, 3(2), 108-113

Amirudin, R. H. (2014). Determinan Kesehatan Ibu dan Anak. Jakarta: CV Trans Info Media

Apriyanti, W. (2015). Hubungan Tingkat Pengetahuan Ibu Hamil tentang Anemia dengan kejadian BBLR di Desa Gebang Kecamatan Patrang Kebupaten Jember.Universitas Jember

Astriana, W. (2017). Kejadian Anemia pada Ibu Hamil Ditinjau dari Paritas dan Usia. Jurnal Aisyah: Jurnal Ilmu Kesehatan, 2(2), 123-130

Asyirah, S. (2012). Faktor - Faktor yang Berhubungan dengan Anemia pada Ibu Hamil di Wilayah Kerja Puskesmas Bajeng kecamatan Bajeng Kabupaten Gowa

Cunningham, F. G., Leveno, K. J., Bloom, S. L., Hauth, J. C., Gilstrap I, L. C., \& Wenstrom, K. D. (2014). Obstetri William Edisi 24. Jakarta: EGC

Dinas Kesehatan Kota Palembang. (2014). Profil Kesehatan Tahun 2013. Dinas Kesehatan Kota Palembang, Palembang

Fatimah, S., Hadju, V., Bahar, B., \& Abdullah, Z. (2011). Pola Konsumsi dan Kadar Hemoglobin pada Ibu Hamil di Kabupaten Maros Sulawesi Selatan. Makara Kesehatan, 15(1), 31-36

Guyton, A. C., \& Hall, J. E. (2011). Buku Ajar Fisiologi Kedokteran Edisi 11. Jakarta: EGC

Kementerian Kesehatan RI. (2014). Profil Kesehatan Indonesia Tahun 2014. Jakarta: Kemenkes RI

Kementerian Kesehatan RI. (2017). Profil Kesehatan Indonesia 2016. Jakarta: Kemenkes

Kementerian Kesehatan RI. (2013). Riskesdas 2013 Badan Penelitian dan Pengembangan Kesehatan Kemenkes RI. Kementerian Kesehatan RI. Jakarta

Krisnawati, K., Desi, A. M. Y., \& Apri, S. (2015). Faktor-Faktor Terjadinya Anemia pada Ibu Hamil Primigravida di Wilayah Kerja Puskesmas Tahun 2015. STIKES Pringsewu Lampung

Mariana, D., Wulandari, D., \& Padila, P. (2018). Hubungan Pola Makan dengan Kejadian Anemia pada Ibu Hamil di Wilayah Kerja Puskesmas. Jurnal Keperawatan Silampari, 1(2), 108-122. https://doi.org/https://doi.org/10.31539/jks.v1i2.83

Nanda, D. D., \& Rodiani, R. (2017). Hubungan Kunjungan Antenatal Care dengan Kejadian Anemia pada Ibu Hamil Trimester III. Majority, 7(1)

Ningrum, A. P., \& Syaifudin, S. (2012). Hubungan Usia dengan Anemia dalam Kehamilan pada Ibu Hamil di Puskesmas Kecamatan Wates Kabupaten Kulon Progo Tahun 2012. STIKES Aisyiyah

Oktaviani, I., Makalew, L., \& Solang, S. D. (2016). Profil Haemoglobin pada Ibu Hamil Dilihat dari Beberapa Faktor Pendukung. Jurnal Ilmiah Bidan, 4(1)

Padila, P. (2015). Asuhan Keperawatan Maternitas 1. Yogyakarta: Nuha Medika 
Qudsiah S. (2012). Hubungan antara Paritas dan Umur Ibu dengan Anemia pada Ibu Hamil Trimester III. Diakses dari: http:jurnal.unimus.ac.id

Rukiyah, A. Y. (2010). Asuhan Kebidanan I (Kehamilan). Jakarta: Trans Info Media Sherwood., I. L. (2011). Fisiologi Manusia. Jakarta: EGC

Sudargo, T., Kusmayanti, N. A \& Hidayati, N. C. (2018). Defisiensi Yodium, Zat Besi dan Kecerdasan. Gadjah Mada University Press. Yogyakarta

Sulistiyanti, A. (2015). Hubungan Tingkat Pengetahuan Ibu Hamil tentang Anemia dengan Kepatuhan Konsumsi Tablet Fe di Wilayah Kerja Puskesmas Masaran 1 Sragen. Jurnal Maternity, 2(2), 1-15

Sulistyawati, A. (2015). Asuhan Kebidanan pada Masa Kehamilan. Jakarta: Salemba Medika

Sumiyarsi, I., Nugraheni, A., Mulyani, S., \& Cahyanto, E. B. (2018). Faktor-Faktor yang Mempengaruhi Hemoglobin Ibu Hamil Trimester III. Placentum, 6(2). https://doi.org/10.13057/placentum.v6i2.22836

Tanziha, I., Rizal, M., Utama, L. J., \& Rosmiati, R. (2016). Faktor Risiko Anemia Ibu Hamil di Indonesia. Jurnal Gizi Pangan, 11(2)

World Health Organization. (2011). Serum Ferritin Concentrations for the Assaament of Iron Status and Iron Deficiency in Populations. World Health Organization, Geneva

World Health Organization. (2014). Maternal Mortality. WHO. Retrieved from http://www.who.int/news-room/fact-sheets/detail/maternal-mortality

World Health Organization. (2015). The Global Prevalence of Anemia in 2011. World Health Organization, Geneva

Yunita, L. (2015). Hubungan Jarak Kehamilan dengan kejadian Anemia pada Ibu Hamil di Puskesmas Kedawung I Kecamatan Karang Malang kabupaten Sragen 